\title{
Systematic UPLC-ESI-MS/MS Study on the Occurrence of Staurosporine and Derivatives in Associated Marine Microorganisms from Eudistoma vannamei
}

\author{
Márcio A. Andréo, ${ }^{a}$ Paula C. Jimenez ${ }^{b}$ Josy B. C. N. Siebra, ${ }^{b}$ Leticia V. Costa-Lotufo, ${ }^{b}$ \\ Ricardo Vessecchi, ${ }^{a}$ Michael Niehues, ${ }^{a}$ João L. C. Lopes ${ }^{a}$ and Norberto P. Lopes ${ }^{*, a}$ \\ ${ }^{a}$ Núcleo de Pesquisa em Produtos Naturais e Sintéticos (NPPNS), Faculdade de Ciências Farmacêuticas de \\ Ribeirão Preto, Universidade de São Paulo, 14040-903 Ribeirão Preto - SP, Brazil \\ ${ }^{b}$ Departamento de Fisiologia e Farmacologia, Faculdade de Medicina, \\ Universidade Federal do Ceará, 60430-270 Fortaleza - CE, Brazil
}

\begin{abstract}
O estudo fitoquímico do invertebrado marinho Eudistoma vannamei levou ao isolamento de derivados do alcalóide estaurosporina, que apresentaram uma potente atividade citotóxica contra linhagens de células humanas de câncer. A ocorrência destes alcalóides pode ser correlacionada a presença de microorganismos associados ao animal, como por exemplo bactérias do gênero Streptomyces. Visando confirmar essa hipótese, precedeu-se o isolamento e cultivo dos microrganismos associados com E. vannamei (84 cepas isoladas). Estudos sistemáticos das reações de fragmentação da estaurosporina e derivados, apoiados pela química computacional, permitiram definir os principais padrões de fragmentação. Esses padrões foram utilizados em análises exploratórias por LC-MS/MS visando pesquisar a presença de derivados de estaurosporinas nos microrganismos isolados. Esse procedimento permitiu identificar estaurosporina em uma espécie de Streptomyces, contudo não com o mesmo padrão de oxidação da molécula ativa isolada no extrato da Ascídia. Finalmente, o extrato dessa cepa mostrou também significativa atividade citotóxica contra linhagens de câncer.
\end{abstract}

Former bioactivity-guided analysis of the marine invertebrate Eudistoma vannamei led to the isolation of staurosporine derivatives, which revealed strong cytotoxic activity against several human cancer cell lines. The occurrence of such alkaloids in E. vannamei may be correlated to the presence of associated biota, such as Streptomyces bacteria. In agreement to this hypothesis, marine microorganisms associated with E. vannamei were recovered and cultured, leading to a total of 84 isolated bacterial strains. Gas phase fragmentation reactions of staurosporine and derivatives were systematically studied and the analyzed results further supported by computational chemistry studies. The resulting fragment patterns were used to search for the presence of different derivatives in extracts of isolated microorganisms, thereby using LC-MS/MS analysis in MRM mode. These results evidenced that one isolated Streptomyces $s p$. was able to generate staurosporine, while none of the hydroxy-7-oxo derivatives were detected. Finally, significant cytotoxic activity against human cancer lines was observed for one of the extracts.

Keywords: Eudistoma vannamei, Streptomyces, staurosporine, LC-MS/MS, ascidian

\section{Introduction}

Historically, the search for bioactive marine natural products has been focused on invertebrate species such as sponges, ascidians and corals. However, different studies suggest that several natural products previously described for marine invertebrates are in fact secondary metabolites produced by microorganisms associated to

*e-mail: npelopes@fcfrp.usp.br these organisms. ${ }^{1,2}$ Eudistoma vannamei is a Brazilian endemic ascidian, whose extract was demonstrated as being highly cytotoxic against several human cancer cell lines. ${ }^{3}$ The bioactivity-guided fractionation of the ethanol extract from the respective ascidian species, suggested the presence of tryptophan derived compounds with strong cytotoxic activity against cancer cell lines. ${ }^{4}$ Further analysis of active fractions led to the identification of two novel alkaloids of the staurosporine type, namely 2-hydroxy7-oxo-staurosporine and 3-hydroxy-7-oxo-staurosporine 
(Figure 1). Cytotoxicity experiments of the alkaloid mixture also revealed strong activity, exhibiting an $\mathrm{IC}_{50}$ value in the nanomolar potency. ${ }^{5}$

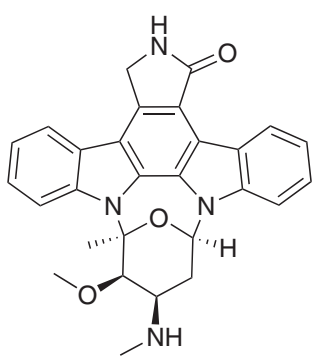

staurosporine

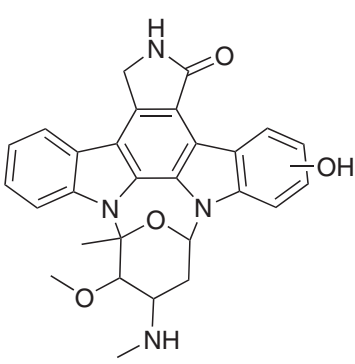

hydroxy-staurosporine

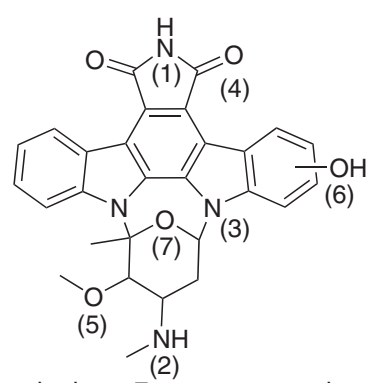

hydroxy-7-oxo-staurosporine

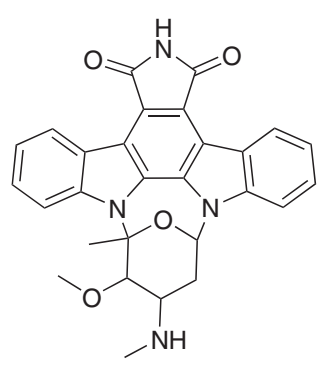

7-oxo-staurosporine
Figure 1. Compounds monitored by LC-MS/MS in MRM mode.

Staurosporine was first isolated in 1977 from Streptomyces staurisporeus and later also from other actinomycetes as well as cyanobacteria. ${ }^{6}$ In the meantime several staurosporine analogues were isolated from actinomycetes $^{5}$ and also from marine invertebrate, including among others sponges, mollusks and tunicates. ${ }^{7-10}$ Interestingly, in several cases staurosporine and related derivatives (Figure 1) were isolated from Streptomyces sp. ${ }^{11}$ The occurrence of such compounds in E. vannamei may suggest the presence of associated microorganisms responsible for the biosynthesis of staurosporine and possible analogues. The LC-ESI-MS/MS technique is a useful tool for the analysis of secondary metabolites at low concentrations in biological samples..$^{12,13}$ For this reason, it also constitutes a good analytical instrument in the identification of staurosporine and its derivatives from associated marine microorganisms. In order to determine chemical structures and their behavior in detail, it is important to define respective gas phase fragmentation reactions, ${ }^{14,15}$ based on systematic parameters investigation $\mathrm{s}^{16}$ and/or computational chemistry. ${ }^{17,18}$ Such experiments offer, for instance, better insights into respective fragmentation pathways and, by that also enable a more sensitive, as well as, selective detection of studied compounds. Taking into account the important biological activity observed for staurosporine, ${ }^{19,20}$ the present work aims at identification the possible producers of staurosporine derivatives among the microbiota recovered from E. vannamei. Furthermore, the occurrence and identification of staurosporine and derivatives from associated microorganisms shall be studied in detail by LC-MS/MS analysis supported by computational chemistry studies.

\section{Experimental}

\section{Chemicals}

Staurosporine was acquired from Sigma Aldrich and hydroxy-7-oxo-staurosporine previously isolated from E. vannamei. ${ }^{5}$ For ESI-MS and ESI-MS/MS analysis the samples were prepared in methanol (HPLC grade) and glacial acetic acid purchased from J.T. Baker (Phillipsburg, NJ, USA). The water was purified with a Milli-Q system (Millipore, Bedford, MA, USA). Cell culture media, fetal bovine serum (FBS) and antibiotics were acquired from Gibco (Grand Island, NY). MTT reagent was obtained from Sigma Aldrich (St. Louis, MO, USA).

\section{Collection of Eudistoma vannamei and isolation of associated bacteria}

Specimens of Eudistoma vannamei were hand collected at Taiba Beach ( $\left.03^{\circ} 30^{\prime} 21.23^{\prime} \mathrm{S} ; 038^{\circ} 53^{\prime} 40.16^{\prime} \mathrm{W}\right)$, located on the northeastern coast of Brazil. Sampling was carried out with the slightest contamination possible, as the material was gathered and stored with sterile utensils. For isolation of microorganisms, the sample was homogenized in sterile seawater and aliquots of $20 \mu \mathrm{L}$ were stroked onto Petri dishes containing different agar based media. The following media were used, supplemented with cycloheximide $50 \mu \mathrm{g} \mathrm{mL}^{-1}$ : SCA (Starch Casein Agar, HIMEDIA, prepared with distilled $\mathrm{H}_{2} \mathrm{O}$ ) and AIA (Actinomycete Isolation Agar, HIMEDIA, prepared in $75 \%$ sea-water).

Purity of strains was resolved by sequential re-strikes onto new agar plates and pure strains then inoculated in fresh liquid medium for culture maintenance and up-scaled growth. Each culture with an isolated strain was sampled with liquid media into cryovials and supplemented with $25 \%$ glycerol for storage at $-70^{\circ} \mathrm{C}$.

\section{Scaled-up growth and extraction}

Pure strains were harvested from agar plates and inoculated in sterile $500 \mathrm{~mL}$ Erlenmeyer flasks with $100 \mathrm{~mL}$ of house-formulated broth containing $2 \%$ glucose, $1 \%$ starch, $1 \%$ hydrolyzed soy and $0.4 \%$ yeast extract in sea 
water. The flasks were left under $200 \mathrm{rpm}$ agitation and $28^{\circ} \mathrm{C}$ for 5 days. The broth was separated from the biomass by filtration and subsequently extracted with ethyl acetate. The solvents were evaporated under vacuum, thus, yielding two organic extracts for each isolated strain.

\section{Screening for cytotoxicity}

Cytotoxic activity of extracts was evaluated against three human tumor cell lines obtained from the National Cancer Institute (Bethesda, MD, USA): MDA-MB-435 (melanoma), SF-295 (CNS glioblastoma) and HCT-8 (colon carcinoma). Cells were grown in RPMI-1640 medium supplemented with $2 \mathrm{mmol} \mathrm{L}^{-1}$ glutamine, $10 \%$ fetal calf serum (FCS), $100 \mu \mathrm{g} \mathrm{mL}^{-1}$ streptomycin and $100 \mathrm{U} \mathrm{mL}^{-1}$ penicillin at $37{ }^{\circ} \mathrm{C}$ in a $5 \% \mathrm{CO}_{2}$ atmosphere. The cell cultures were regularly split to keep them in logarithmic growth phase.

At first, in a qualitative approach, the effect of $100 \mu \mathrm{g} \mathrm{mL}^{-1}$ of each extract dissolved in DMSO on tumor cell viability was evaluated in vitro using the MTT assay. ${ }^{21}$ Cells were incubated with extracts for $72 \mathrm{~h}$ in 96-well plates. At the end of the incubation period, the medium of each well was replaced by fresh media containing $0.5 \mu \mathrm{g} \mathrm{mL}{ }^{-1}$ of the MTT [3-(4,5-dimethyl-2-thiazolyl)-2,5diphenyl-2H-tetrazolium bromide] (Sigma Aldrich Co., St. Louis, MO, USA) reagent and left for another $3 \mathrm{~h}$. The cells were centrifuged and the supernatant then discarded. The generated formazan salt was diluted in DMSO and the absorbance detected with a multiplate reader (DTX 880 Multimode Detector, Beckman Coulter, Inc. Fullerton, California, USA) at $570 \mathrm{~nm}$. Those extracts considered active (that reduced cell viability by over $75 \%$ ) were tested again in a serial dilution, with concentrations varying between 0.02 and $100 \mu \mathrm{g} \mathrm{mL}^{-1}$. Staurosporine $\left(1 \mu \mathrm{g} \mathrm{mL}^{-1}\right.$; $2 \mu \mathrm{M})$ was used as positive control. In result of the detected cell viabilities, the $50 \%$ inhibitory concentration $\left(\mathrm{IC}_{50}\right)$ was calculated, along with the respective 95\% CI (confidence interval), by non-linear regression using the software GraphPad Prism 5.0 (Intuitive Software for Science, San Diego, CA).

Identification of bacteria: nucleic acid extraction, 16S rRNA gene amplification, and sequencing

Genomic DNA extraction from the selected microorganism was carried out using a CTAB-based protocol. ${ }^{22}$ Concentration and quality of DNA extractions were measured using a Nanodrop Spectrophotometer ND1000 (NanoDrop, Wilmington, DE, USA). The 16S rRNA gene was partially amplified from genomic DNA by PCR using primers $63 \mathrm{~F}$ (5' -CAG GCC TAA CAC ATG CAA GTC-3') and 1389R (5'-GGG CGG WGT GTA CAA GGC- $\left.3^{\prime}\right) .{ }^{23}$ Amplification reactions were performed in a final volume of $25 \mu \mathrm{L}$ containing $100 \mathrm{ng}$ of genomic DNA (template), $20 \mathrm{mmol} \mathrm{L}^{-1}$ Tris- $\mathrm{HCl}$ ( $\mathrm{pH} 8.4$ ), $50 \mathrm{mmol} \mathrm{L}^{-1}$ $\mathrm{KCl}, 1.5 \mathrm{mmol} \mathrm{L}^{-1} \mathrm{MgCl}_{2}, 200 \mu \mathrm{mol} \mathrm{L}^{-1}$ of each nucleic acid (dATP, dCTP, dGTP and dTTP), $0.5 \mu \mathrm{mol} \mathrm{L}^{-1}$ of each primer and 1.0 units of Taq DNA Polymerase (MBI Fermentas Inc., USA). PCR reactions were carried out in a thermocycler (Eppendorf AG 22331; Eppendorf, Hamburg, GER) programmed for an initial denaturation step (4 min at $94{ }^{\circ} \mathrm{C}$ ) followed by 35 cycles of $1 \mathrm{~min} 94^{\circ} \mathrm{C}, 1 \mathrm{~min}$ at $55^{\circ} \mathrm{C}$ and $2 \mathrm{~min}$ at $72^{\circ} \mathrm{C}$. The last cycle was followed by a $10 \mathrm{~min}$ final extension at $72{ }^{\circ} \mathrm{C}$. The specificity of amplifications was confirmed by $1 \%$ agarose gel electrophoresis stained with SYBR Safe DNA Gel Stain (Invitrogen, USA). PCR products were purified using Wizard SV Gel and PCR Clean-up System (Promega Corporation, Madison, WI, USA).

DNA sequencing was performed by Macrogen Inc. (Seoul, Korea) using the ABI PRISM BigDye ${ }^{\mathrm{TM}}$ Terminator Cycle Sequencing kit (Applied Biosystems, Foster City, CA, USA) following the protocols supplied by the manufacturer. The sequencing reactions were performed using the primers $63 \mathrm{~F}, 1389 \mathrm{R}, 518 \mathrm{~F}\left(5^{\prime}\right.$-CCA GCA GCC GCG GTA ATA CG-3') and 800R (5'-TAC CAG GGT ATC TAA TCC-3'). The fluorescent-labeled fragments were purified using an ethanol precipitation protocol, resuspended in distilled water and subjected to electrophoresis in an ABI 3730 sequencer (Applied Biosystems, Foster City, CA, USA). The nucleotide sequences were assembled, analyzed, and manually edited using the Sequencher software package (version 4.5; Gene Codes Co., Ann Arbor, MI) and compared to sequences within the NCBI database (http://www.ncbi.nlm.nih.gov/) using the Basic Local Alignment Search Tool (BLAST). The nucleotide sequence was submitted to NCBI GenBank and is available under the accession number JN703426.

\section{HPLC-DAD-ESI-MS/MS and UPLC-MS/MS analysis}

Samples were injected into a HPLC system (ShimadzuLC 6AD) equipped with a Diode Array Detector (Shimadzu-SPD M10A). Routine detection was performed at $324 \mathrm{~nm}$. The separation was profiled on a LC-column (Shimadzu-ODS-C18, $5 \mu \mathrm{m}, 250 \times 4 \mathrm{~mm}$ i.d.), using a $\mathrm{MeOH} / \mathrm{H}_{2} \mathrm{O}$ system (with $1.0 \%$ acetic acid) as mobile phase. A linear gradient from $20 \%$ to $100 \% \mathrm{MeOH}$ was applied in a period of $60 \mathrm{~min}$. For HPLC-DAD-ESI-MS/MS analysis, the samples were injected into a HPLC system (Shimadzu-LC 20AD) equipped with a Diode Array 
Detector (Shimadzu-SPD M20A). The separation was performed at the conditions previously established.

High resolution electrospray ionization mass spectrometry (HR-ESI-MS) were acquired in positive ion mode and recorded on a hybrid quadrupole-time of flight instrument (UltrOTOF-Q, Bruker Daltonics, Billerica, MA). Conditions: capillary voltage $3400 \mathrm{~V}$; dry gas temperature, $180{ }^{\circ} \mathrm{C}$; dry gas flow, $4 \mathrm{~L} \mathrm{~h}^{-1}$ and nitrogen as nebulizer gas. $\mathrm{Na}^{+} \mathrm{TFA}$ (sodiated trifluoroacetic acid) $10 \mathrm{mmol} \mathrm{L}^{-1}$ was used as standard for internal calibration.

Low Resolution Analyses were performed with a Waters Acquity ${ }^{\mathrm{TM}}$ (Milford, MA, U.S.A.) ultra performance liquid chromatography (UPLC) system, connected to a Acquity ${ }^{\mathrm{TM}}$ triple quadrupole mass spectrometer $(\mathrm{QqQ})$. For the analysis a ACQUITY UPLC ${ }^{\circledR}$ BEH C18 column was used $(1.7 \mu \mathrm{m}$ pore size, $2.1 \times 50 \mathrm{~mm}$ ). The chromatographic conditions were as followed: $0.3 \mathrm{~mL} \mathrm{~min}{ }^{-1}$ flow, $30^{\circ} \mathrm{C}$ column and $20^{\circ} \mathrm{C}$ sample temperature. The mobile phase used was $\mathrm{MeOH} /$ $\mathrm{H}_{2} \mathrm{O}$ (with $1.0 \%$ acetic acid), applying a linear gradient from $20 \%$ to $100 \%$ of $\mathrm{MeOH}$ over $15 \mathrm{~min}$. Fractions and the chemical reference staurosporine were diluted in $\mathrm{MeOH}$ to a concentration of $20 \mu \mathrm{g} \mathrm{mL}^{-1}$ and $10 \mu \mathrm{g} \mathrm{mL}-1$, respectively. From each $5 \mu \mathrm{L}$ were injected for analysis.

The analysis on QqQ was carried out in an electrospray ionization (ESI) source, in the positive mode. The source block and desolvation temperatures were kept at $150{ }^{\circ} \mathrm{C}$ and $250{ }^{\circ} \mathrm{C}$, respectively. Nitrogen was used as both, drying and nebulizing gas and argon as collision gas. MS parameters were optimized by direct infusion of the chemical reference staurosporine. The transitions $\mathrm{m} / \mathrm{z}, 467>338$ and $m / z, 467>130$ were monitored for staurosporine, $m / z, 497>368$ and $m / z, 497>130$ for hydroxy-7-oxostaurosporine, $m / z, 483>130$ for hydroxy-staurosporine as well as $\mathrm{m} / \mathrm{z}, 481>352$ and $\mathrm{m} / \mathrm{z}, 481>130$ for 7-oxostaurosporine. Conditions for staurosporine were tuned to attain higher sensitivity and values transferred for transitions of the other derivatives. In summary, collision energy was set at $24 \mathrm{eV}$ for transitions to the fragment at $\mathrm{m} / \mathrm{z}, 130$ and at $18 \mathrm{eV}$ for remaining transitions. The cone and capillary voltages were set at $36 \mathrm{~V}$ and $3.7 \mathrm{kV}$, respectively. Qualitative analysis of fractions and reference were performed by multiple reaction monitoring (MRM) of the protonated molecules $\left([\mathrm{M}+\mathrm{H}]^{+}\right)$and their corresponding ions with a well time of $0.025 \mathrm{~s}$. For this purpose the MassLynx data sampling software (Waters), version 4.1, was employed.

\section{Computational methods}

All molecules had their geometries optimized by applying the BP86/6-31+G(d,p $)^{24,25}$ model interfaced with Gaussian 03 software. ${ }^{26}$ The minimum at potential energy surface was indicated by analysis of the harmonic frequencies. Protonation sites were indicated by analyzing the molecular electrostatic potential map (MEP) and proton affinities (PA), which were obtained through calculation of the enthalpies values for protonated and neutral species following the equation: $\mathrm{M}+\mathrm{H}^{+} \rightarrow \mathrm{MH}^{+}$. All molecules were visualized at Molekel 5.0 software. ${ }^{27}$

\section{Results and Discussion}

Eighty four colonies were recovered from $E$. vannamei of which 17 were elected for bioactivity evaluation on tumor cells, 6 isolated in AIA and 11 in SCA media. In the qualitative screening, it was noticeable that broth extracts were generally more cytotoxic than those from remaining biomass (Figure 2). Furthermore, the ethyl acetate extract derived from EVA 01063 was clearly the most active among the tested strains, reducing viability of all cell lines by over $75 \%$. $\mathrm{IC}_{50}$ for the ethyl acetate extract of EVA 01063 was quite low, ranging from 0.75 to $1.30 \mu \mathrm{g} \mathrm{mL}^{-1}$, whereas, the methanol extract ranged between 22 and $79 \mu \mathrm{g} \mathrm{mL}^{-1}$ (Table 1). BLAST analysis of the 16S sequence obtained for EVA 01063 determined that this strain belonged, indeed, to the Streptomyces genus.

Crude ethyl extracts of the selected Streptomyces strain were analyzed by HPLC-ESI-MS. The HR-ESI-MS spectra were acquired in positive ion mode and the results are present at Figure S1 (see Supplementary Information). The analysis of hydroxy-7-oxo-staurosporine in the extracts applying TOF analyzer was not conclusive. The UV chromatogram may suggest the presence of the cytotoxic compounds at minor concentrations; but, in this particular case, the TOF analyzer could not provide confident results for the presence or absence of hydroxy-7-oxostaurosporine. Nevertheless, a systematic investigation of the gas phase fragmentation reactions of protonated staurosporine (a possible precursor of hydroxy-7-oxostaurosporine) was performed, applying for this purpose Q-TOF and QqQ analyzers. These data are important to define strategies for multiple reaction monitoring (MRM) and/or neutral loss experiments in QqQ devices, which increase the sensitivity and are an excellent tool to analyze metabolites at low concentration in biological samples. ${ }^{28}$

Our research group has studied heterocyclic alkaloids in order to understand the fragmentation mechanism for these compounds under collision. ${ }^{29}$ Thus, on the basis of the observation, the initial step for the fragmentation studies was to define the possible protonation sites. ${ }^{17,18}$ In order to identify these regions in staurosporine derivatives, the proton affinities (PA) and molecular electrostatic potential map (MEP) calculations were done and all the compounds 

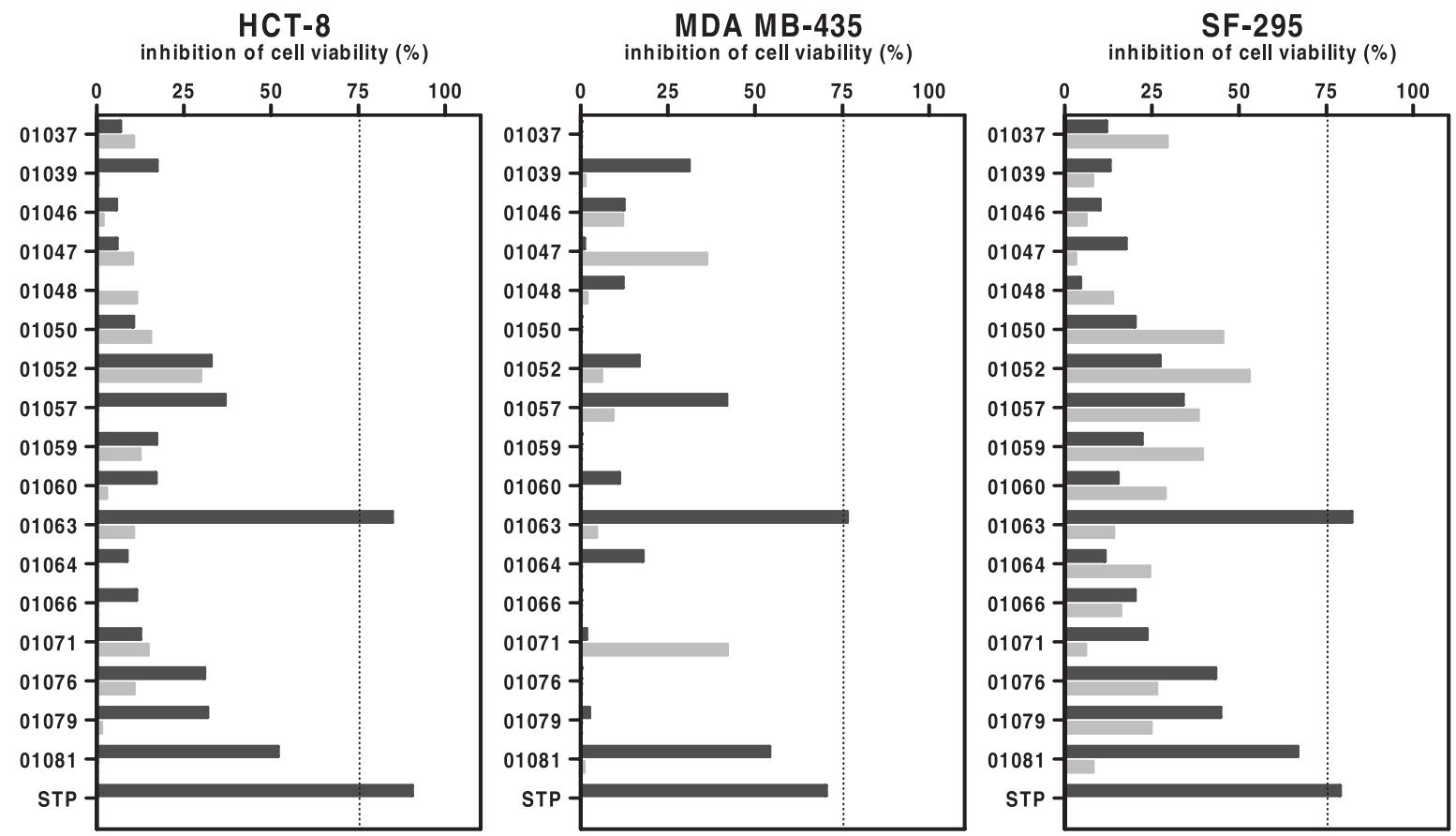

Figure 2. Single dose $\left(100 \mu \mathrm{g} \mathrm{mL}^{-1}\right)$ cytotoxic activity of ethyl acetate extract from broth (dark gray) and methanol extract from biomass (light gray) of selected bacterial strains recovered from $E$. vanname $i$ evaluated against HCT-8, MDA-MB-435 and SF- 295 cell lines by the MTT assay after $72 \mathrm{~h}$ incubation. Staurosporine (STP, $\left.1 \mu \mathrm{g} \mathrm{mL}^{-1}\right)$ was used as positive control. Data obtained from two independent experiments $(\mathrm{n}=3)$ are presented as a percentage of cell viability inhibition relative to untreated cells $(100 \%)$.

Table 1. Cytotoxic activity of extracts obtained from strain EVA 01063 recovered from E. vannamei. Broth and biomass extracts were tested on HCT-8, MDA MB-435 and SF-295 cell lines and evaluated by the MTT assay after $72 \mathrm{~h}$ incubation. Staurosporine was used as positive control

\begin{tabular}{lccc}
\hline Sample & HCT-8 & MDA MB-435 & SF-295 \\
\hline Broth & $0.97^{\mathrm{a}}$ & $1.30^{\mathrm{a}}$ & $0.75^{\mathrm{a}}$ \\
(ethyl acetate) & $(0.79-1.19)$ & $(0.91-1.84)$ & $(0.63-0.89)$ \\
Biomass & $34.20^{\mathrm{a}}$ & $79.57^{\mathrm{a}}$ & $22.39^{\mathrm{a}}$ \\
(methanol) & $(25.03-46.73)$ & $(68.00-93.12)$ & $(18.67-26.86)$ \\
Staurosporine & $0.04^{\mathrm{a}}$ & $0.10^{\mathrm{a}}$ & $0.27^{\mathrm{a}}$ \\
& $(0.03-0.05)$ & $(0.07-0.14)$ & $(0.21-0.34)$ \\
\hline
\end{tabular}

${ }^{\mathrm{a}} \mathrm{CC}_{50}\left[\mu \mathrm{g} \mathrm{mL}{ }^{-1}\right]$ values and their respective $95 \%$ confidence intervals (values in brackets) were obtained by nonlinear regression on the GraphPad Prism 5.0 software (Intuitive Software for Science, San Diego, CA).

showed the same behavior, Figure 3. The most basic regions (nucleophilic) in the MEP are indicated by red color (using the staurosporine and hydroxy-7-oxo staurosporine models), showing that the possible protonation sites are the nitrogen and oxygen atoms in the molecule (Figure 3). The PA values for these possible protonation sites (Table 2 ) were obtained as described at the experimental section. The most stable protonation site is indicated by the highest value of PA. In this case, the nitrogen (2) and the oxygen (4) atoms are the most probable protonation site, respectively (Table 2). These results are useful to understand the reactivity under collision-induced dissociation (CID) conditions for these compounds. Protonation in $\mathrm{O}(4)$ indicates that the reactivity of staurosporine derivatives may be compared to the lactam rings, where the proton is located at carbonyl. ${ }^{30}$

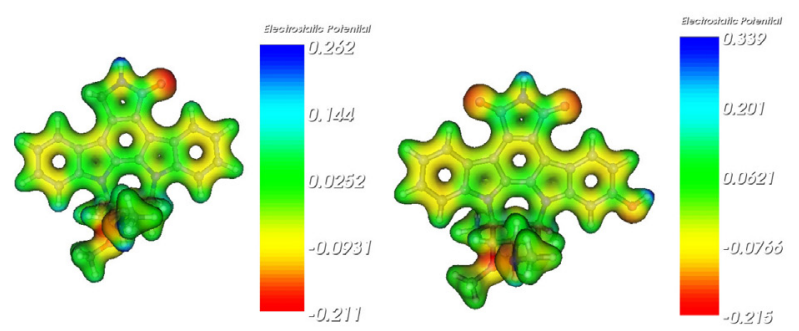

Figure 3. Molecular electrostatic potential map (MEP) for staurosporine and hydroxy-7-oxo-staurosporine.

Thus, on the basis of these two possible protonation sites and PA values, two main competitive fragmentation pathways were suggested from the protonated molecule of the staurosporine derivatives (for fragment ions spectra see Figure 4). The most stable protonated specie occurs when the proton take place at N(2) (Table 2) and, pathway A (Figure 5) triggers by a concerted mechanism. In this case, the protonation site is fundamental for this reaction and the proton migration produces the ion at $\mathrm{m} / \mathrm{z}, 130$ (see Figure 5). The $m / z, 130$ can eliminate a ketene affords the final ion at $m / z$ 88. Both ions have the same mass values for all analyzed staurosporine derivatives and present the best choice for MRM analysis. 
Table 2. Proton affinity values (PA) and relative enthalpies $\left(\Delta \mathrm{H}_{298}\right)$, in $\mathrm{kcal} \mathrm{mol}^{-1}$, for hydroxy-7-oxostaurosporine (for the respective atom number, number between parenthesis, see Figure 1), obtained by BP86/6-31+G(d,p) model

\begin{tabular}{lccccccc}
\hline Atom & $(1)$ & $(2)$ & $(3)$ & $(4)$ & $(5)$ & $(6)$ & $(7)$ \\
\hline PA & 219.1 & 230.8 & 210.6 & 221.4 & 197.1 & 186.3 & 195.3 \\
$\Delta \mathrm{H}_{298}$ & 11.8 & 0 & 20.3 & 9.4 & 33.7 & 44.5 & 35.6 \\
\hline
\end{tabular}
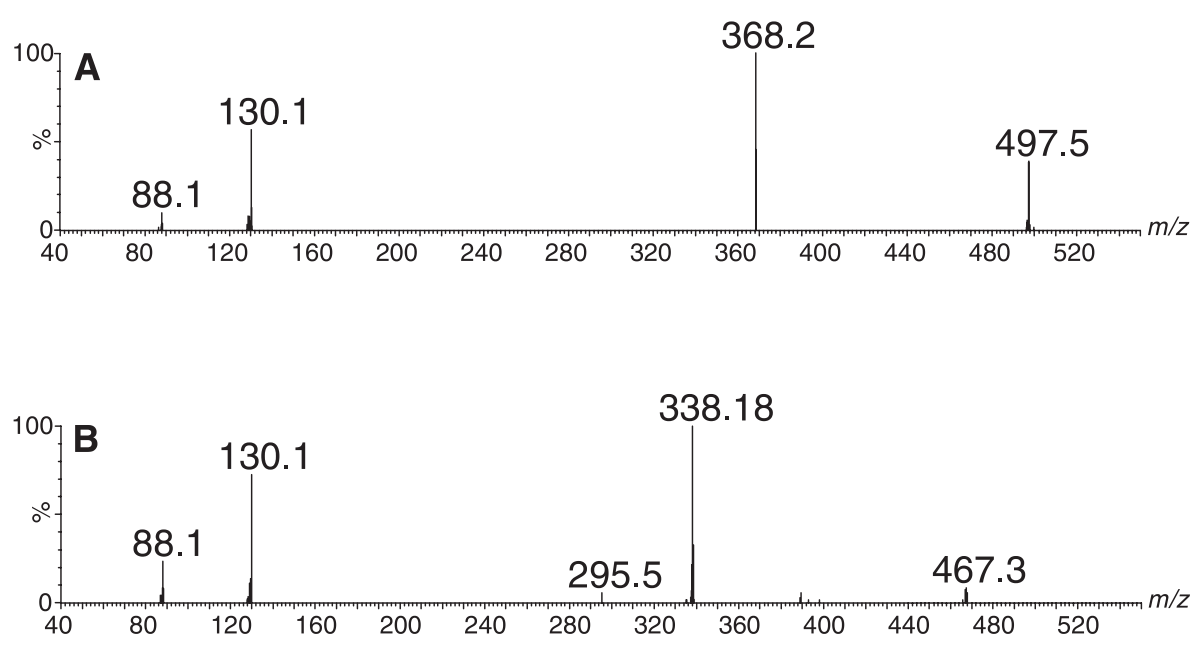

Figure 4. Mass spectra from ESI-MS/MS analysis of hydroxy-7-oxostaurosporine (A) and staurosporine (B).

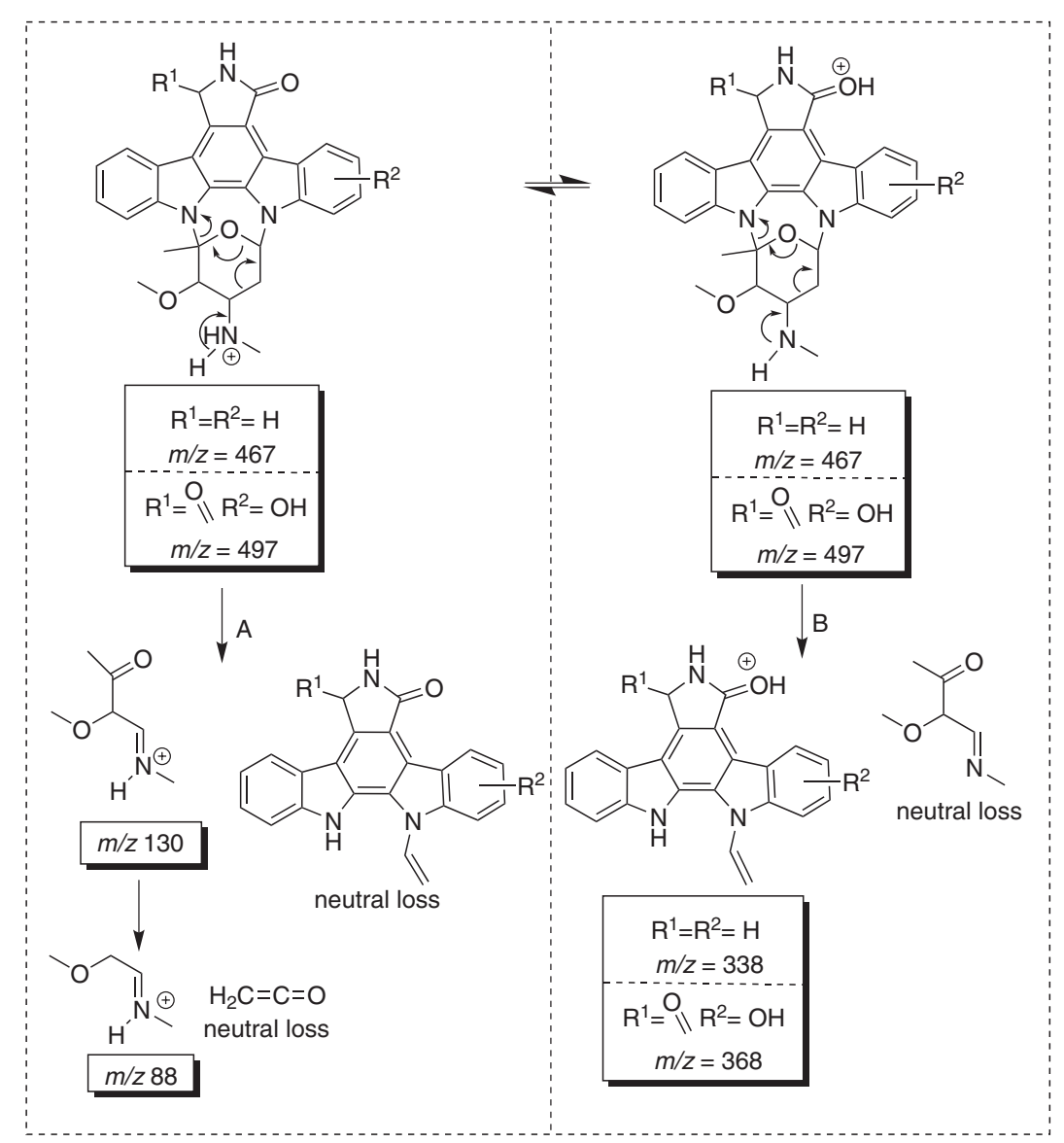

Figure 5. Major fragment ions observed and their corresponding fragmentation mechanisms for staurosporine derivatives. 

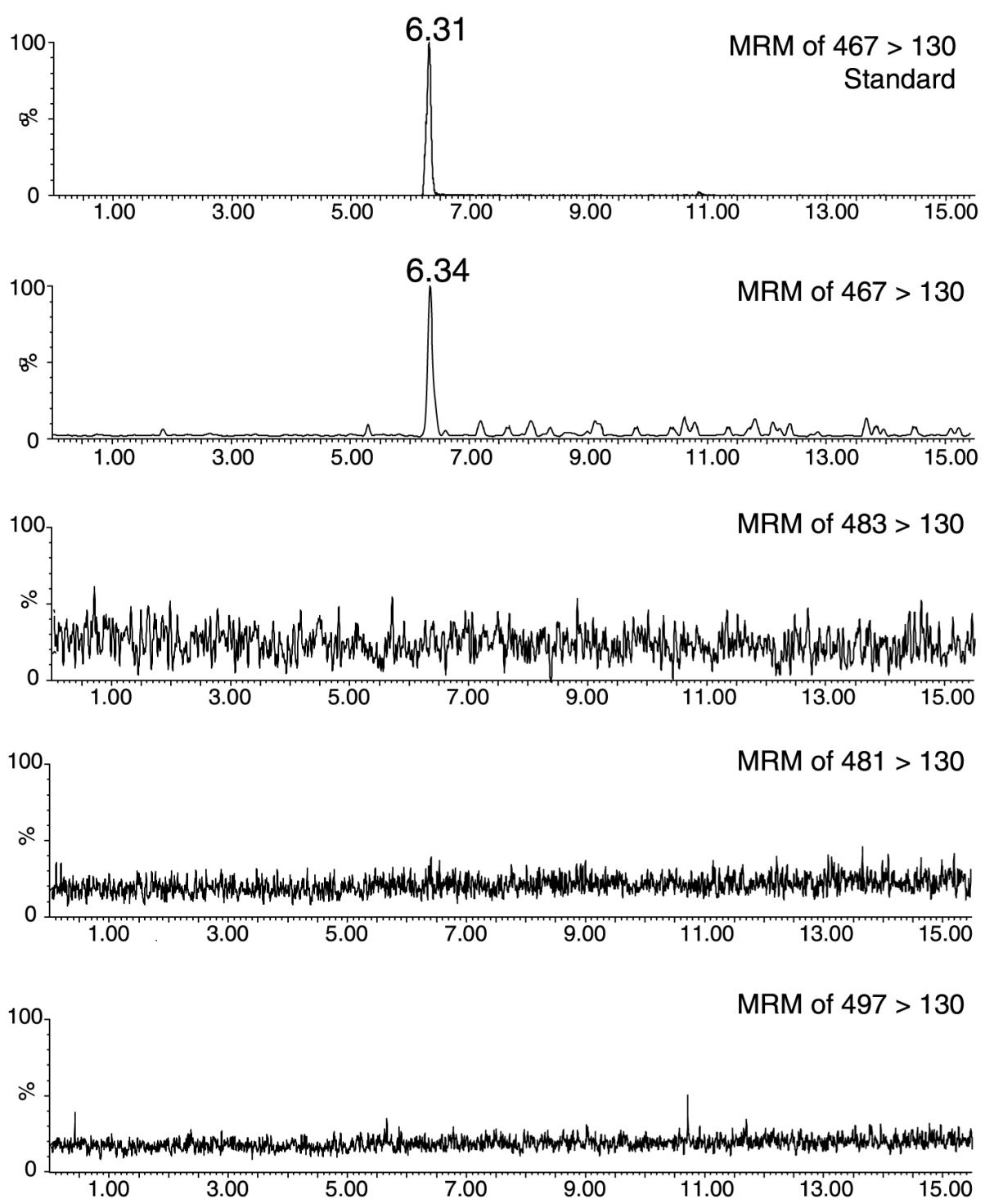

Figure 6. UPLC-MS/MS analysis in MRM mode of staurosporine (standard) and the selected extract (EVA 01063) from the Streptomyces sp. Respective $\mathrm{m} / \mathrm{z}$ transitions are indicated in the MS spectra. X-axis: min; Y-axis: relative signal intensity.

Pathway B occurs when proton take place in $\mathrm{O}(4)$ (lactam ring) through a charge remote mechanism by a neutral elimination, which similar to the ones observed from other marine natural products, ${ }^{21}$ exhibiting ions at $\mathrm{m} / \mathrm{z} 338$ and 368 for staurosporine and hydroxy-7-oxostaurosporine, respectively (Figure 5). The ion at $\mathrm{m} / \mathrm{z} 338$ can fragment, by a ring contraction, to form the ion of the $\mathrm{m} / \mathrm{z} 295$. The low intensity of this ion is in agreement of the low stability observed for three membered rings, and the second carbonyl function of hydroxy-7-oxo-staurosporine completely inhibits the ring contraction mechanism.

Four channels of protonated molecules were selected to perform the MRM analysis of the compound described in Figure 1. In a preliminary analysis the reference staurosporine was used at $10 \mu \mathrm{g} \mathrm{mL}^{-1}$ to verify the detection capacity of the UPLC-ESI-MS/MS method and to optimize
MS settings for the MRM analysis. Tuning experiments performed by direct infusion at $36 \mathrm{~V}$ cone energy and $20 \mathrm{eV}$ collision energy, exhibited the priory described fragments for staurosporine (Figure 5B), showing the protonated molecule $[\mathrm{M}+\mathrm{H}]^{+}$at $\mathrm{m} / \mathrm{z} 467.3$ and the correspondent fragments at $m / z 338.18,285.5,130.1$ and 88.1. The MRM analysis evidenced that the selected strain (01063) accumulates staurosporine and does not accumulate or generate the derivatives 7-oxo-staurosporine, hydroxy-7oxo-staurosporine and hydroxy-staurosporine.

\section{Conclusions}

The electrospray ionization mass spectrometric analysis of extracts from the isolated Streptomyces strain 01063 demonstrated the presence of staurosporine, 
but none of the derivatives.. These results suggest that microorganisms associated to E. vannamei are responsible for the accumulation and possibly also for the biosynthesis of staurosporine, which has already been reported for other Streptomyces spp. The isolation of staurosporine derivatives, such as hydroxy-7-oxostaurosporine, from E. vannamei extracts, therefore, indicates that staurosporine was oxidized after secretion by the associated microorganisms, for instance, on their cell surface or surrounding environment. Alternatively, it could suggest that this sequential reaction of staurosporine in the extracellular medium just does not occur under the performed Streptomyces sp. cultivation conditions. On the other hand, metabolization of staurosporine by the marine invertebrate itself should also be considered. Further studies are necessary to clarify in which way derivatives, such as the hydroxy-7-oxo-staurosporine, affect the known cytotoxic activity of staurosporine.

\section{Supplementary Information}

Supplementary data are available free of charge at http://jbcs.sbq.org.br as a PDF file.

\section{Acknowledgements}

FAPESP, CNPq, CAPES for the financial support.

\section{References}

1. Jensen, P. R.; Fenical, W. In Drugs from the Sea; Fusetani, N. ed.; S Karger: Basel, 2000, p. 6.

2. Penesyan, A.; Kjelleberg, S.; Egan, S.; Mar. Drugs 2010, 8, 438.

3. Jimenez, P. C.; Fortier, S. C.; Lotufo, T. M. C.; J. Exp. Mar. Biol. Ecol. 2003, 287, 93.

4. Jimenez, P. C.; Wilke, D. V.; Takeara, R.; Comp. Biochem. Physiol. Part A. 2008, 151, 391.

5. Jimenez, P. C.; Wilke, D. V.; Takeara, R.; Ferreira, E. G.; Lotufo, T. M. C.; Pessoa, C. O.; Moraes, M. O.; Silveira, E. R.; Lopes, N. P.; Costa-Lotufo, L., V.; Planta Med. 2008, 74, 933.

6. Sanchez, C.; Mendez, C.; Salas,J. A.; Nat. Prod. Rep. 2006, 23, 1007.

7. Cantrell, C. L.; Groweiss, A.; Gustafson, K.R.; Boyd, M. R.; Nat. Prod. Res. 1999, 14, 39.

8. Meragelman, K.M.; West, L.M.; Northcote, P.T.; Pannell, L. K.; McKee, T. C.; Boyd, M.R.; J. Org. Chem. 2002, 67, 6671.

9. Schupp, P.; Proksch, P. ; Wray, V.; J. Nat. Prod. 2002, 65, 1046.

10. Reyes, F.; Fernandéz, R.; Rodriguez, A.; Bueno S.; de Eguilior C. ; Francesch A. ; Cuevas, C.; J. Nat. Prod. 2008, 71, 1046.

11. Omura, S.; Sasaki, Y. ; Iwai, Y.; J. Anitibiot. 1995, 48, 535.
12. Gobbo-Neto, L.; Lopes, N. P. ; J. Agr. Food Chem. 2008, 56, 1193.

13. Xing, J.; Xie, C.; Lou, H.; J. Pharm. Biomed. Anal. 2007, 44, 368.

14. Fonseca, T.; Lopes, N. P.; Gates, P. J.; Staunton, J.; J. Am. Soc. Mass Spectrom. 2004, 15, 325.

15. Kind, T.; Fiehn, O.; Bioanal. Rev. 2010, 2, 23.

16. Lopes, N. P.; Stark, C. B. W.; Hong, H.; Gates, P. J.; Staunton, J.; Analyst. 2001, 126, 1630.

17. Vessecchi, R.; Galembeck, S. E.; Lopes, N. P.; Nascimento, P. G. B. D.; Crotti, A. E. M.; Quim. Nova. 2008, 31, 840.

18. Vessecchi, R.; Emery, F. S.; Galembeck, S. E.; Lopes, N. P.; Rapid Comm. Mass Spectrom. 2010, 24, 2101.

19. Rüegg, U. T.; Gillian, B.; Trends Pharmacol. Sci. 1989, 10, 218.

20. Karaman, M. W.; Herrgard, S.; Treiber, D. K.; Gallant, P.; Atteridge, C. E.; Campbell, B. T.; Chan, K. W.; Ciceri, P.; Davis, M. I.; Edeen, P. T.; Faraoni, R.; Floyd, M.; Hunt, J. P.; Lockhart, D. J.; Milanov, Z. V.; Morrison, M. J.; Pallares, G.; Patel, H. K.; Pritchard, S.; Wodicka, L. M.; Zarrinkar, P. P.; Nat. Biotechnol. 2008, 26, 127.

21. Cardozo, K. H. M.; Vesecchi, R.; Carvalho, V. M.; Pinto, E.; Gates, P. J.; Colepicolo, P.; Galembeck, S. E.; Lopes, N. P.; Int. J. Mass. Spec., 2008, 273, 11.

22. Warner, S. J. In Plant Gene Isolation: Principles and Practice, Foster, G. D.; Twell, D., eds.; John Wiley \& Sons: West Sussex, 1996, 51.

23. Marchesi, J. R.; Sato, T.; Weightman, A. J.; Martin, T. A.; Fry, J. C.; Hiom, S. J.; Dymock, D.; Wade, W. G.; Appl. Environ. Microbiol. 1998, 64, 795.

24. Becke, A. D.; Phys. Rev. A. 1998, 38, 3098.

25. Perdew, J. P.; Phys. Rev. B. 1986, 33, 8822.

26. Frisch, M. J.; Trucks, G. W.; Schlegel, H. B.; Scuseria, G. E.; Robb, M. A.; Cheeseman, J. R.; Montgomery, J. A., Jr.; Vreven, T.; Kudin, K. N.; Burant, J. C.; Millam, J. M.; Iyengar, S. S.; Tomasi, J.; Barone, V.; Mennucci, B.; Cossi, M.; Scalmani, G.; Rega, N.; Petersson, G. A.; Nakatsuji, H.; Hada, M.; Ehara, M.; Toyota, K.; Fukuda, R.; Hasegawa, J.; Ishida, M.; Nakajima, T.; Honda, Y.; Kitao, O.; Nakai, H.; Klene, M.; Li, X.; Knox, J. E.; Hratchian, H. P.; Cross, J. B.; Bakken, V.; Adamo, C.; Jaramillo, J.; Gomperts, R.; Stratmann, R. E.; Yazyev, O.; Austin, A. J.; Cammi, R.; Pomelli, C.; Ochterski, J. W.; Ayala, P. Y.; Morokuma, K.; Voth, G. A.; Salvador, P.; Dannenberg, J. J.; Zakrzewski, V. G.; Dapprich, S.; Daniels, A. D.; Strain, M. C.; Farkas, O.; Malick, D. K.; Rabuck, A. D.; Raghavachari, K.; Foresman, J. B.; Ortiz, J. V.; Cui, Q.; Baboul, A. G.; Clifford, S.; Cioslowski, J.; Stefanov, B. B.; Liu, G.; Liashenko, A.; Piskorz, P.; Komaromi, I.; Martin, R. L.; Fox, D. J.; Keith, T.; Al-Laham, M. A.; Peng, C. Y.; Nanayakkara, A.; Challacombe, M.; Gill, P. M. W.; Johnson, B.; Chen, W.; Wong, M. W.; Gonzalez, C.; Pople, J. A.; Gaussian 03, revision A.1; Gaussian, Inc.: Wallingford, CT, 2004. 
27. Varetto, U. <MOLEKEL 5.0>; Swiss National Supercomputing Centre: Manno (Switzerland).

28. Wang, J.; Mass. Spectrom. Rev. 2009, 28, 50.

29. Crotti, A. E. M.; Gates, P. J.; Lopes, J. L. C.; Lopes, N. P.; Mol. Nutr. Food Res. 2010, 54, 433.
30. Abboud, J.-L. M.; Cañada, T.; Homan, H.; Notario, R.; Cativiela, C.; Diaz de Villegas, M. D.; Bordojé, M. C.; Mó, O.; Yáñez, M.; J. Am. Chem. Soc. 1992, 114, 4728.

Submitted: November 18, 2011 Published online: February 7, 2012

FAPESP has sponsored the publication of this article. 